\section{Matthew Weinbaum*}

\section{"Implications of Automotive Emission Restrictions in California"}

* Matthew Weinbaum recently graduated from the University of Michigan where he studied Political Science, History and Environmental Studies. He is planning on either attending law school or pursuing a graduate degree in Political Science.

\section{Introduction}

This report explains how California has historically enacted regulation curtailing conventional pollutants and greenhouse gas emissions. By examining previous California automotive emission controls that have led to the development of similar standards across the country, it can be argued that California has the capacity to be a leader in climate change policy and greenhouse gas emission standards in the future. This means that the air pollution problems of the state are not a burden, but rather an incentive to develop a policy countering global warming at the federal level. In this analysis, a rationale is established for interest groups to aim at California state regulations if they wish to improve automotive emission policy in the United States, and potentially reduce the effects of global warming worldwide.

In late July 2002, California Governor Gray Davis signed Assembly Bill (AB) 1493 into the state law. The bill authorizes the California Air Resource Board (CARB) to "adopt regulations that achieve the maximum feasible, costeffective and technologically achievable reduction of greenhouse gas pollution emitted by new passenger vehicles [by 2005]."1 This legislation represents a victory for environmentalists looking to impact global climate change in California. However, the true significance of this bill lies in its national implications. Its passage ensures that, for the very first time, carbon dioxide emissions for transportation will be regulated at all levels of government within the United States.2 Additionally, as the fifth largest world economy and $13 \%$ of the US car market, California's ratification of $\mathrm{AB} 1493$ has the potential to force car

\footnotetext{
${ }^{I}$ See, e.g., Assembly Bill 1493: Legislation to Reduce Global Warming Pollution from New Passenger Vehicles in California, Bluewater Network, at

$<$ http://www.bluewaternetwork.org/reports/rep_ca_global_ab1493facts.pd $f>$

${ }^{2}$ Raymond Haynes, Criminalizing Carbon Dioxide, Metropolitan News ENTERPRISE, July 19, 2002, at 7.
}

manufacturers to adopt California emission standards throughout the US.3

The passage of AB 1493 is only one recent example of how California emission standard upgrades in automobiles at the state level have eventually led to the elevation of these measures at the national level. Since 1970, California has been a leader in establishing progressive auto emission standards. This is possible due to a loophole in the original Federal Clean Air Acts that stipulate California as the only state to set its mobile source emission standards higher than those set nationally. However even prior to 1970, California was at the forefront of all types of air pollution control legislation. In fact, the reason the state was granted the option to establish its own automotive emission standard under the Federal Clean Air Act of 1970 was because the California Air Resource Board predates the federal government's Environmental Protection Agency.4 The first part of this report examines the time period when California became the leader within the US in not only automotive emission legislation but also in overall air pollution controls. The purpose of this discussion is to describe the precedent, which has been established in the 'Golden State', to enact progressive environmental legislation.

The passage of AB 1493 is used as a case study to describe the political and legislative maneuvering that led to California Governor Gray Davis signing the bill into law on July 22, 2002. This is illustrated along a timeline that effectively tracks how interest groups can influence climate change legislation at the state level. After reviewing the passage of $\mathrm{AB}$ 1493, it is understood that a blueprint can be established for interest groups to influence California greenhouse gas automotive emission standards in the future.

After examining how AB 1493 was passed, the potential national and international repercussions of this action is displayed. As a result, it can be argued that California has the ability to force car manufacturers to Trade Up. In other words, the state can force car manufacturers to produce all of their cars, nationally and internationally, according to its statewide emission standards. However, although California can set higher greenhouse gas emission standards for automobiles by forcing car manufacturers to Trade Up to its standard, it is important to recognize why the state would be willing to do this. This is especially true as some scientists assert that greenhouse gas emissions of individual US states account for only small portions of these emissions worldwide.5

\footnotetext{
${ }^{3}$ William Booth, California Takes Lead on Auto Emissions: Gov Davis to sign law on pollution that may affect all US drivers, WASHINGTON POST, July 22, 2001, at A1; also see Mark Martin, State's air law to steer nation; Automakers fear spread of car emission policy, SAN FRANCISCO ChronicLe, July 21, 2002, at A1 [hereinafter Mark Martin].

${ }^{4}$ See Tom Valtin, California Emissions Bill Paves Way for Cleaner Cars, Sierra Club, at http://www.sierraclub.org/planet/200209/cleaner_cars.asp (last modified Sept/Oct, 2002).

${ }^{5}$ See, e.g., Eric Pianin, On Global Warming, State Acts Locally at Odds With Bush's Rejection of Mandatory Cuts. Governors and Legislatures
} 
Others contend that the threat of global warming, a purported outcome of the emission of greenhouse gases, is in itself exaggerated. As Michael Parsons, in his book Global Warming: The Truth Behind the Myth, states:

\begin{abstract}
...after an open-minded evaluation of the scientific facts, it cannot honestly be stated that global warming is happening. We cannot say that the Earth is any warmer today than it was 100 years ago, nor can we say that it would be bad for humanity if it were! 6
\end{abstract}

Thomas Moore even maintains that individuals and groups who have a monetary incentive to support enhanced climate change legislation exaggerate the effects of global warming.

It is also true that people believe what is in their interest to believe. If global climate change is viewed as a threat, environmental organizations can raise more support from the public; politicians can posture as protectors of mankind; newspapers can write more scary stories, thus increasing circulation; and scientists, even those most skeptical, can justify research grants to study the issue. 7

Despite global warming naysayers, there is evidence that point towards climate change as a significant problem in the future. In June 2002, the US State Department sent an Environmental Protection Agency report to the United Nations, which acknowledged that man-made sources of greenhouse gas emissions are primary contributors to global warming.8 Additionally, in June 2002 Timothy Egan of the New York Times reported the effects of global warming on the State of Alaska. He cited the destruction of a fourmillion-acre spruce forest by beetles - average temperature rise in the state of seven degrees over the last 30 years and how sea ice has retreated by $14 \%$ off the Alaskan coast since 1978 as rationale for believing that the threat of global warming is legitimate. 9

While the threat of global warming may be genuine, there is an obvious lack of consensus within the United States as to what the effects of a warmer planet will be. As a result, it has become increasingly difficult to pass federal legislation that effectively addresses the problem. For instance, President Bush's Clear Skies Initiative does not limit the amount of carbon dioxide that companies emit. Instead, it calls for companies to voluntarily reduce the amount of carbon dioxide that they produce 'per unit of economic output'.10 However in California, legislation

Enact Curbs on Greenhouse Gases, WASHINGTON Post, Nov 11, 2003, at A03.

${ }^{6}$ Michael Parsons, Global Warming: The Truth Behind the Myth 241 (Insight Books 1995).

7 Thomas Gale Moore, Climate of Fear 3 (Cato Institute 1998).

${ }^{8}$ See In Denial on Warming, Boston GloBe, Dec 9, 2002, at A9

${ }^{9}$ See also Timothy Egan, Alaska, No Longer So Frigid, Starts to Crack, Burn and Sag, NEW YORK TIMES - LATE EDITION, June 16, 2002, at Section 1, Page 1, Column 3

${ }^{10}$ See Mr. Bush Dissembles, The St. Louis Post - DisPatch, June 11, 2002, at B6 curbing greenhouse gases and conventional air pollutants is consistently passed ahead of national legislation. As a result, it might seem as if citizens of California have more of a pro-environment lean than other US citizens. People who believe this argue that there is something intrinsic about Californians that make them environmentally concerned and willing to address the state's problems. This, however, is not the case. Rather, specific factors within California drive down the cost of compliance with regards to climate change regulations in comparison to most other US states. 11

Understanding why and how progressive auto emission standards originate in California explains why it may be possible for interest groups to recognize when similar legislation can be enacted in the state's future. In concluding this report, it is demonstrated that the present 'laggard' federal policy on climate change simply represents an added incentive for environmentalists to pass such legislation within the 'Golden State'. This is because California's AB 1493 illustrates that the state can effectively enact regulations curbing greenhouse gases where the federal government has failed to do so.

\section{California and Proactive Air Pollution Controls (1950 - present)}

To interpret the history of progressive auto emission standards in California, it is also important to understand the history of overall air quality standards within the state. Since the end of World War II, California has displayed the foresight to enact air quality programs and policies that have led the rest of the country to improve upon their standards as well. A primary reason for this is because scientific research has helped develop a proactive response to air pollution problems by the state under the auspices of the California Air Resource Board (CARB) - a subdivision of CalEPA.12 When reviewing the history of California air pollution control, it is apparent that a precedent for enacting progressive automotive emission legislation was established in California prior to the passage of AB 1493.

The root of California's proactive measures against air pollution originated in the reactionary 1947 California Air Pollution Control Act.13 This initial act can be considered

\footnotetext{
${ }^{11}$ See infra DAVID Vogel, TRAdING UP: CONSUMER AND

ENVIRONMENTAL REGULATION IN A GLOBAL ECONOMY 258-9 (2nd Ed 1995) [hereinafter TRADING UP].

${ }^{12}$ The Air Resource Board is one of six branches of CalEPA along with Department of Pesticide Regulation, the Department of Toxic Substances Control, the Integrated Waste Management Board, the Office of Environmental Health Hazard Assessment and the State Water Resources Control Board. All of these branches act with autonomy under the general 'umbrella' of CalEPA, which is led by the office of the secretary. The secretary's job is to "provide vision and leadership that focuses the efforts of the boards, departments and offices of CalEPA." About: Cal/EPA Office of the Secretary, California Environmental Protection Agency, at $<$ http://www.calepa.ca.gov/About/OfficeSec.htm> (visited Feb 6, 2003).

${ }^{13}$ This is seen in Los Angeles County being the first county to establish an air pollution control district. It did this in 1947 when the Air Pollution Control Act was passed. The next counties to develop these districts did
} 
reactionary, because it was established only after smog was accepted as a public health concern for residents within the Los Angeles Basin. The act "authorized the creation of an air pollution control district in every county of the state," in which these newly established districts were given broad powers to adopt and enforce air regulations.14 This initial legislation against air pollution in the state had nearly unanimous support among state politicians in California. 15 However, as the state and its citizens recognized the severity of the air pollution in southern California, politicians and scientists began to search for a better understanding of what caused smog, in order to more accurately address the problem. As a result, in 1952 Dr. Arie Haagen-Smit, a biochemist at the California Institute of Technology, discovered how ozone, a main ingredient in smog, was created. He recognized that "driven by sunlight, a photochemical reaction combined hydrocarbons from oil refineries and the partially unburned exhaust of automobiles with nitrogen oxides, a combustion byproduct, to form ozone".16

By determining that ozone was a principle factor in the smog around metropolitan Los Angeles, Dr. Haagen-Smit established the foundation upon which the air pollution standards of today are measured.17 By understanding what more specifically caused smog to form in Los Angeles, it became possible for California to confront the problem before its severity increased. As a result, the state established itself as a leader in air pollution prevention. This is seen as far back as the mid-1950s when California created America's first air quality program and passed the nation's first far-reaching Clean Air Act to encourage research on the origins of air pollution. 18

In 1959, California enacted laws that asserted the role of the Department of Public Health in regulating automotive emissions. This again positioned California as a state leader in air pollution prevention. Additionally, in 1961, ahead of national legislation, the California Motor Vehicle Pollution Control Board and the State Bureau of Air Sanitation mandated the first automotive emissions control technology.19 By understanding more about the individual components of smog, a state policy shift from reactionary to proactive in its legislation of air pollution continued through the 1960s. In 1966 the California Motor

not come until Riverside, San Bernadino and some in the Bay Area did this in the 1950s. See The Southland's War on Smog: Fifty Years of Progress

Towards Clean Air, Southern Coast Air Quality Management District, at

$<\mathrm{http}: / /$ www.aqmd.gov/monthly/marchcov.html $>$ (visited April 3, 2003).

${ }^{14}$ See California Air Quality History - Key Events, California Air

Resource Board, $a t<\mathrm{http}: / / \mathrm{www}$. arb.ca.gov/html/brochure/history.htm $>$

(visited April 10, 2003)

${ }^{15}$ There was only one dissenter against the bill in the State house and no dissenters in the Senate.

${ }^{16} \mathrm{Id}$.

${ }^{17}$ See History of California Environmental Protection Agency, CalEPA, at http://www.calepa.ca.gov/about/History01/calepa.htm (visited May 8, 2003).

${ }^{18}$ See California Air Quality History - Key Events, supra note 14

${ }^{19} \mathrm{Id}$.
Vehicle Pollution Control Board made California the first state to adopt standards for car tailpipe emissions.20 A year later, the California Air Resource Board (CARB) was created through the merger of the California Motor Vehicle Pollution Control Board and the Bureau of Air Sanitation and its Laboratory. To this day, CARB has guarded the role of its predecessors as a national leader in air pollution control standards. Since its inception in 1967, CARB has conducted extensive scientific research for California in order to develop solutions for the state's air pollution dilemmas, both in and outside the Los Angeles Basin. For example, CARB's research has found a link between slow lung function growth and long-term exposure to outdoor pollution. Furthermore, a current project is seeking to determine the effects of air pollutants on asthmatic children.21

CARB's research capability can be attributed to the size and professionalism of the agency itself. In total, CARB has roughly 850 employees working in Sacramento and Del Monte with an operating budget of $\$ 163.2$ million for the 2003-04 fiscal year funded by the state.22 Directing CARB are ten board members picked with the consent of the State Senate by the government. Five of these board members are from local air quality boards throughout the state. Three others are from specific professional backgrounds, engineering, ecology, physics, etc., and the remaining two are appointed from the public sector. All members of the board are part time employees, with the exception of the chairperson who is full time. The State Governor chooses the chairperson from among the ten board members.

The credibility of CARB's research has played an important role in the creation of environmental laws aimed at attacking air pollution within the State of California. In the late 1960 s, CARB and its preceding agencies worked to implement automotive emission standards for the state as it laid the foundation for the first national motor vehicle emission standard and the formation of the federal Clean Air Acts of 1970. An outcome of these acts was that CARB obliged automotive manufactures to meet the first standards controlling for hydrocarbon and nitrogen oxide emissions. 23

The relationship between CARB research and subsequent California action to improve upon present air quality emission standards continues today. By recognizing the danger of air pollution to California, particularly to the

\footnotetext{
${ }^{20} I d$.

${ }^{21}$ See Air Resource Board, CalEPA, at

$<$ http://www.calepa.ca.gov/about/History01/arb.htm> (visited Sept 27, 2002).

${ }^{22}$ Telephone Interview with Public Information Office, California Air Resource Board (Feb 17, 2003); also, see California Department of Finance, Environmental Protection, 2003 - 04 Governor's Budget, at $<$ http://www.osp.dgs.ca.gov/On-

Line+Publications/Governor's+Budget+2003-2004.htm> (visited April 3, 2003).

${ }^{23}$ Air Resource Board, supra note 21.
} 
Los Angeles metropolitan area, stringent laws have been enacted and enforced to protect citizens from this public evil. Consider automotive tailpipe regulation within the state:

Since 1984, the state claims to have reduced harmful auto emissions by $17 \%$ through its $\mathrm{I} / \mathrm{M}$ program. This progress is due to the stringent tailpipe standards and to the diligence of the testing. According to 1987 EPA data, California had the highest failure rates $(25 \%)$ of any of the more than twenty states audited. When a car fails the I/M test, it must be modified to reduce its emissions. Thus, high failure rates reflect diligent testing...The state's goal is to achieve $25 \%$ reduction in tailpipe emissions through its $\mathrm{I} / \mathrm{M}$ program by 1994.24

By the late 1980s and early 1990s, California, as a state and CARB as a state agency, firmly established themselves as leaders in developing progressive air pollution control policies. California was ranked as having the strongest state regulatory program for air pollution out of all US state programs according to a Fund for Renewable Energy and the Environment's (FREE) State of the State: 1987 report. 25

In 1988, CARB helped California adopt its own amendments to the Federal Clean Air Act. These amendments eventually served as the basis for the Federal Clean Air Act Amendments of 1990.26 Also in 1990, California adopted CARB-sponsored legislation that instructed automakers to make a certain percentage of their total passenger cars sold in the state by 1998 either low emission or zero emission vehicles.27 However, in January 2002, a lawsuit was filed in US District Court against the implementation of CARB-approved 2001 zero emission vehicle amendments to the 1990 legislation. As a result of this lawsuit on behalf of automotive companies and dealerships, a temporary injunction was placed against the implementation of new ZEV standards that were to affect 2003 and 2004 car models. 28

\section{Case Study: The Passage of California Assembly Bill 1493}

The nearly sixty year history of California air pollution controls leads to the signing of AB 1493 by Governor Gray Davis on July 21, 2002. Again, the passage of California

\footnotetext{
${ }^{24}$ See Will Lowry, The Dimensions of Federalism: State GOVERNMENTS AND POLLUTION CONTROL POLICIES 92 (1992).

${ }^{25}$ EVAN J RINQUIST, ENVIRONMENTAL PROTECTION AT THE STATE LEVEL: POLITICS AND PROGRESS IN CONTROLLING POLLUTION 105, 105-108 (1993) [hereinafter ENVIRONMENTAL PROTECTION AT THE STATE LEVEL].

${ }^{26}$ See History of California Environmental Protection Agency, supra note 17

${ }^{27}$ Danny Hakim, California is Moving to Guide US Policy on Pollution, THE NEW YorK TIMES, July 3, 2003, at Section A, Page 1, Column 5 [hereinafter Danny Hakim, California is Moving to Guide US Policy on Pollution].

${ }^{28}$ Appendix B: Description of Litigation Involving the Zero Emission Vehicle Regulation, California Environmental Protection Agency, at $<$ http://www.arb.ca.gov/regact/zev2003/appb.pdf $>$ (visited April 4, 2003)>.
}

Assembly Bill 1493 can be seen as a landmark victory in the battle against climate change and global warming. However, there is mutual agreement among politicians on both sides of $\mathrm{AB} 1493$ that this measure would not have been adopted without the strong lobbying efforts of environmental interest groups.29 As a result, it is important to understand the role environmental interest groups played in the passage of $\mathrm{AB} 1493$ to recognize how progressive climate change policy can be passed within California in the future. A path is traced of $\mathrm{AB} 1493$ from its predecessor AB 1058 into California state law to demonstrate this point.

AB 1058 was an Assembly Bill sponsored by the Bluewater Network, an environmental interest group out of San Francisco, and authored by state assembly member Fran Pavley.30 It was introduced on February 23, 2002. The purpose of this bill was almost identical to that of its successor AB 1493. Its passage would have given a primary role to $\mathrm{CARB}$ in setting emission standards for motor vehicles in California. At the time that $\mathrm{AB} 1058$ was introduced, there was widespread support for California to take a lead in the arena of climate change legislation. According to public opinion polls released in February 2002, by the Public Policy Institute of California, 59\% of adults and $62 \%$ of likely voters believed it was worth passing more stringent environmental legislation, even if there was an economic downside. 31 However, this initial bill submitted for legislation did not clearly define the limits of CARB's powers in setting emission standards. As a result, opponents of the legislation spent nearly $\$ 1$ million per week - after its initial passage in the state Senate on April 24th, 2002 - in order to point it out to the California public.32 Car manufacturers and car dealers in California spearheaded the opposition to the bill. They feared increased manufacturing costs with the passage of the legislation. Opponents of AB 1058 successfully swayed public opinion through television, newspaper and radio advertisements claiming that the legislation would give CARB unrestrained power to determine what and when Californians could drive. They pointed to a recent report from CARB that offered several costly ways to reduce vehicle emissions, despite the fact that none of these suggestions would have been allowed under AB 1058.

\footnotetext{
${ }^{29}$ See Danny Hakim, California is Moving to Guide US Policy on Pollution, supra note 27.

${ }^{30}$ Pavley has been a State assembly member in 2000 . She serves the $41^{\text {st }}$ Assembly district, which includes Agoura Hills, Calabana, Encino, Hidden Hills, Malibu, Pacific Palisades, Port Hueneme, Oak Park, Santa Monica, Tarzana, Topanga, portions of Oxnard and West Lake Village. She is on eight committees in the house and she is the chair of two of them; the select resources committee and the committee on air and water quality. In 2002 she was appointed as one of five assistant majority whips in the State assembly. See Fran Pavley, Biography, Assembly Member 41st District, at $<$ http://democrats.assembly.ca.gov/members/a41/default2.htm?biography $>$ (visited April 10, 2003)

${ }^{31}$ See Mark Baldassare, PPIC Statewide Survey: Californians and Their Government, PUB. POL'Y INST. OF CAL., Feb 2002, at VI.

${ }^{32}$ See Robert T. Garrett, Green Car Bill Stalls Again, THE PRESSENTERPRISE, May 17, 2002, at A01.
} 
Suggestions in the report included a 50 cent-per-gallon increase in the price of gasoline, reducing speed limits or adding surcharges of as much as $\$ 3,500$ on automobiles that get poor gas mileage. 33 In part due to the misleading statements of AB 1058 opponents, some state representatives indicated they would not support the bill because of increased opposition from within their jurisdictions. As a result, by early-May 2002 the bill stalled in the California house despite earlier passage in the State Senate. 34

$\mathrm{AB}$ 1493, also sponsored by the Bluewater Network and Fran Pavley, was presented in mid-May 2002 when it was certain that $\mathrm{AB} 1058$ would not get the votes needed for ratification by the State House of Representatives. This new bill was simply a modified $\mathrm{AB} 1058$ that better explained the limits of CARB's power to reduce greenhouse gas emissions from automobiles. To gain support for this new legislation, the Bluewater Network created outreach programs to build grassroots support. Within these programs, the organization explained the limits of AB 1493 in order to explicitly address the amount of authority CARB would have under such legislation. This was done to refute the claims of those against the legislation.

Aside from simply refuting the claims of the automotive industry, the Bluewater Network and other environmental interest groups explained to Californians the potential dangers associated with increased levels of greenhouse gas emissions in the atmosphere. The Bluewater Network did this by referencing a report by the United Nations Intergovernmental Panel on climate change, which predicted an increase of 10.4 degrees in the Earth's temperature over the next century. Additionally, the Bluewater Network argued that although California's population represents $.5 \%$ of the entire world, it accounts for almost $7 \%$ of global $\mathrm{CO} 2$ emissions.35 They stressed that automobiles were a primary source of carbon dioxide emissions, and thus the place where the greatest reductions in emissions would be possible. 36

In a joint effort to pass $A B$ 1493, the California Air Resource Board (CARB) offered additional information about the risks that California's environment faced due to global warming and how the bill could reduce those risks. In CARB presentations, explaining the benefits of enhanced automotive regulations, the agency illustrated the effects that global warming has for the Earth in general and the

\footnotetext{
${ }^{33}$ See, e.g., Mark Martin, Bill to Cut Greenhouse Gases Idles in Assembly, SAN FRANCISCO CHRONICLE, May 22, 2002, at A21 [hereinafter Greenhouse Gases Bill Idles]

${ }^{34}$ Howard Posner, Bill Analysis: AB 1493, California Legislative Information, at

$<$ http://www.leginfo.ca.gov/pub/0102/bill/asm/ab_14511500/ab_1493_cfa 20020701_191016_asm_floor.html> (visited April 10, 2003); $\underline{\text { See also }}$ $\overline{i d}$.

${ }^{36}$ Telephone Interview with Christine Corwin, Bluewater Network (Oct 30, 2002)
}

State of California in particular. The agency explained the direct effects that greenhouse gas emissions have for the state's water, shoreline and air quality. CARB, like the Bluewater Network, also clarified how transportation in California is the principal source $(58 \%)$ of the greenhouse gas carbon dioxide within the state. Furthermore, information presented by CARB pointed out the restrictions on its power that was explicitly stated in the legislation. 37

Through considering every stakeholder that would potentially be affected by this public health problem, environmental interest groups and CARB raised awareness of the risks associated with air pollution. This may have been an effective tactic in garnering public support for $\mathrm{AB}$ 1493.

The clean cars bill [AB 1493] has broad support from leading figures in the technology industry. It is a top priority for the American Lung Association of California and nearly all the state's major environmental organizations. Supporters also include the California Teacher's Association, California Nurses Association and the California Professional Firefighters.

Local government support comes from the cities of Los Angeles, San Jose, San Diego and San Francisco, as well as the Bay Area Air Quality Management District and water management authorities in Marin County, Santa Clara County and the East Bay. US Senators Feinstein and Boxer and a majority of the House delegation are also backing the bill. AB 1493 has been endorsed by the Los Angeles Times, the Sacramento Bee, the San Francisco Chronicle and the San Jose Mercury News. 38

However, even after $\mathrm{AB} 1058$ was modified into $\mathrm{AB}$ 1493, the automotive industry still attempted to derail support for the legislation. Opposing both of these bills was the Alliance of Automobile Manufactures (AAM). The AAM is a trade association composed of ten car/light truck manufacturers whose members (BMW, Daimler-Chrysler, Ford, GM, Mazda, Mitsubishi, Nissan, Porsche, Toyota and Volkswagen) account for $90 \%$ of US vehicle sales.39

AAM and others conducted a similar campaign to deflect support from AB 1058. They claimed that AB 1493, like its predecessor, would impose a tax on drivers of SUVs, that it would tax drivers based on miles/gallon driven and that the bill would make cars lighter and less safe. This is despite the fact that AB 1493 explicitly states that CARB would not be allowed to do any of these things in creating emission standards. Statements made by AB 1493 opponents were refuted by The National Resources Defense Council in

\footnotetext{
${ }^{37}$ This lobbying effort is illustrated by a PowerPoint presentation made public after the passage of the legislation. California Air Resource Board, Global Warming and the Greenhouse Gas Emissions from Automobiles, at <www.arb.ca.gov/gcc/092602board/092602bdpres.pdf> (visited Dec 11, 2002)

${ }^{38}$ See, e.g., Press Release, The Natural Resources Defense Council, California's Clean Car Legislation (July 22, 2002) (on file with http://www.nrdc.org/media/pressreleases/020722.asp).

${ }^{39}$ Alliance of Automotive Manufacturers, About the Alliance, at $<$ http://www.autoalliance.org/about.htm $>$ (visited April 3, 2003).
} 
press releases and on its website. A sample of this is seen in table 2-1 below. 40

\section{Table 2-1 \\ SETTING THE RECORD STRAIGHT}

Out-of-state carmakers are financing a multi-million dollar media campaign that ignores the facts and makes false claims to scare voters and decision makers into opposing AB 1493. Some of these claims follow, along with the truth.

The claim: AB 1493 would "force all drivers to pay much more in the form of gas taxes and mileage fees." (Allen Zaremberg, President, California Chamber of Commerce)

The truth: The California Air Resources Board has no authority to levy gasoline taxes or impose mileage fees, and AB 1493 would not provide it with such authority.

The claim: AB 1493 "sets the stage for huge increases in the cost of owning and driving vehicles in California." (Phil Isenberg, Spokesman for the Coalition against AB 1493)

The truth: $A B 1493$ would require that the regulations are "economical to an owner or operator of a vehicle, taking into account the full life-cycle costs of a vehicle." (AB 1493, Sec.3 (i) (2) (B))

The claim: "AB 1493 is an open-ended blank check that would empower the Air Resources Board to decide what products we can offer our customers." (Avery Greene, President, California Motor Car Dealers Association)

The truth: AB 1493 would prohibit the Air Resource Board from banning "the sale of any vehicle category in the state, specifically including, but not limited to, sport utility vehicles and light-duty trucks."

The claim: "AB 1493 gives the California Air Resources Board a blank check to decide . . . how many miles you drive." (Paid newspaper advertisement by opponents of AB 1493)

The truth: AB 1493 would prohibit CARB from imposing any limitations on driving.

The claim: "They're even talking about charging two cents for every mile you drive and 50 cents per gallon more in gas taxes." (paid advertisement by California Motor Car Dealers Association, Sacramento Bee, 5/6/02, p. A7)

The truth: As noted above, the California Air Resources Board has no authority to levy gasoline taxes or impose mileage fees and AB 1493 would not provide it with such authority.

\footnotetext{
${ }^{40}$ See, e.g., Natural Resources Defense Council, Automakers' Campaign of Lies and Distortion Against California's Clean Car Legislation, Clean Cars Now, $a t<$ www.cleancarsnow.org/presskit/carmakerdistortions.pdf $>$ (visited May 6, 2003)
}

The claim: AB 1493 "lets state bureaucrats push for huge new taxes on minivans, pickups and SUVs." (radio advertisement transcribed from www.wedrive.org)

The truth: Once again, the California Air Resources Board has no authority to levy gasoline taxes or impose mileage fees, and AB 1493 would not provide it with such authority.

The efforts of the automotive industry to halt the passage of AB 1493 offer evidence that automotive interest groups are willing to mislead the public in order to derail support for enhanced automotive emission regulation. As a result, there are no guarantees that Californian automotive regulations will be upgraded after CARB's mandate under AB 1493 expires in 2009. Other factors might hinder the work of interest groups to pass similar legislation as well.

A major problem with passing legislation aimed at reducing greenhouse gas emissions is that the cost-benefit analysis is uncertain so long as there is not a widespread consensus on the future impact of these emissions.41 Additionally, the point is made time and again that a reduction of California automotive emission standards would only contribute to a minor reduction in overall emission standards for the rest of the world. If all other states outside of California decided to maintain their levels of pollution in light of California's reduction, the passage of these automotive regulations may have a greater cost than benefit to Californians.

To address these problems in passing AB 1493, the Bluewater Network and other interest groups made it clear to Californians that their state's legislation would reach beyond its boundaries.42 Christine Corwin, of the Bluewater Network, maintains that although the bill was drafted with the purpose of affecting only California automotive emissions, the public was told that the bill could have impacts beyond the state as well.43 Sean Peterson, a member of AB 1058 and AB 1493 sponsor Fran Pavley's staff, said that he anticipated a natural movement among states to accept California's new regulatory standards. 44 Everyone involved, including the principal organization opposed to the bill, acknowledged that the passage of $A B$ 1493 would have the potential to impact legislation beyond the State of California. As Josephine Cooper, Alliance of Automotive Manufacturers argues:

Federal law and common sense prohibit each state from developing its own fuel economy standards. Because of the impact on the entire national economy, 20 years ago Congress reserved the issue of fuel economy standards to the federal government in order to balance all sectors of the

\footnotetext{
${ }^{41}$ Norman J. Vig AND Michael E. KRAFT, ENVIRONMENTAL POLICY 196, 191 - 196 (2000) [hereinafter ENVIRONMENTAL POLICY].

${ }^{42}$ Telephone Interview with Sean Peterson, Staff Member for California Assemblywoman Fran Pavley (Oct 30, 2002).

${ }^{43}$ Telephone Interview with Christine Corwin, supra note 36.

${ }^{44}$ Telephone Interview with Sean Peterson, supra note 42.
} 
economy and to avoid a patchwork quilt of state regulation. 45

Although AAM and other automotive interests successfully halted the passage of AB 1058, June 2002 opinion polls conducted by the Public Policy Institute of California, only one month before the bill's ratification, show that Californians were still in favor of legislation curbing greenhouse gas emissions from automobiles. By this time, $81 \%$ of those surveyed said that they supported AB 1493. Additionally, $77 \%$ of SUV owners said that they were in favor of this bill as well.46

In the passage of $\mathrm{AB} 1493$, voting in both the State House and Senate occurred primarily along party lines. In the Senate, the bill was passed on June 29, 2002 by a margin of 23-16. No Republican voted in favor of the legislation and only three Democrats voted against it. A similar trend occurred in the California house as the bill was passed by a count of 41 to 30 . Once again no Republican voted in favor of the legislation and only three Democrats voted against it.47 This is inconsistent with how other climate change policies have been enacted within other US states.48 After ratification in the state house and Senate, AB 1493's last stop before becoming law was the desk of California Governor Gray Davis who, during an election year, had an added incentive to sign a high-profile piece of environmental legislation.

From January 2002 through July 2002, Governor Davis's support against his Republican rival Bill Simon dropped from a $9 \%$ lead to a $7 \%$ lead according to a poll conducted by the Field Institute for the Sacramento Bee.49 The decline in Davis's lead also coincided with an increase in apathy for both politicians among state residents. This is in part because Davis ineptly handled the energy crisis, fundraised too aggressively and mishandled an Oracle software contract, while the IRS investigated Simon for fraud.50 Therefore, it was in Governor Gray Davis's

\footnotetext{
${ }^{45}$ See Press Release, Josephine Cooper, Automakers Will Pursue Litigation to Protect California Consumers (July 22, 2002) (on file with Alliance of Automotive Manufacturers at

$<$ www.autoalliance.org/pressreleases/pr072202.htm>).

${ }^{46}$ See Mark Baldassare, Special Survey on Californians and the Environment, PUB. POL'Y INST. OF CAL., June 2002, at 6 [hereinafter Special Survey]

${ }^{47}$ California Taxpayers Association 2002 Legislative Voting Record, Assembly Members,

$a t<$ http://www.caltax.org/VoteScorecardAssembly.pdf> (visited May 8, 2003).

${ }^{48}$ E.g., Barry Rabe, Greenhouse and Statehouse: The Evolving State Government Role in Climate Change, Pew Center on Global Climate CHANGE, November 2002, at 9 .

${ }^{49}$ See Amy Chance, Davis Keeps Lead on Simon: Despite Unfavorable Ratings, the Governor Edges His GOP Rival, SACRAMENTO BEE, July 11, 2002, at

$<$ www.sacbee.com/content/politics/ca/election/polls/story/3528415p4554552c.html>.

${ }^{50}$ See Laura Kurtzman, Poll: Davis and Simon Both Losing Support

Among Voters, MERCURY NeWS, September 4, 2002, at

$<$ http://www.bayarea.com/mld/mercurynews/4004426.htm>
}

political interest to sign AB 1493 into state law on July 21, 2002 in order to give his sagging popularity a boost.

\section{Effects of California Auto Emission Legislation Nationally and Internationally}

The passage of $\mathrm{AB} 1493$ is important because the new California automotive emission standard that CARB adopts in 2006 has the potential to become the national and international standard for automotive emissions. One way this is possible is by other US states adopting California's standard over the national standard. The US limits emission restrictions placed on cars to two categories: those set by the Federal EPA and those set by California. Therefore, if California enacts stricter automotive emission regulations, other US states legally have the option to choose between the US standard and the California standard. Past evidence supports this as an innovative and successful way to adopt higher automotive standards for the entire nation.

As of late 2002, four states-Maine, Vermont, New York and Massachusetts-adopted California's car emissions legislation. This move is a precursor for these states to adopt CARB standards for car emissions when they are established under AB 1493 in 2005.51 Tom Moye, the section chief for Vermont's mobile source station, explains the rationale behind these states accepting the California standard over the national standard:

As a general statement, the California emissions standards are a more effective way of helping to address air pollution from vehicles than the federal standards. While I can't predict whether or not California standards will become the national standard, I do know that the California standards have significantly influenced the national standards (i.e., made them more stringent). 52

The other way in which California regulations can become accepted as the national standard is if car manufacturers using the California criterion as their standard for all cars they produce. This is a likely scenario because California controls 13\% of the United States automotive market.53 The ability of California to affect the national standard of car manufacturers can be related to a process coined by David Vogel as Trading Up.

The idea of Trading Up is simple. A wealthy and powerful state first raises the regulatory standards for goods within its jurisdiction. Assuming a state that often increases its production standard is one that is affluent and captures a considerable portion of the market, producers are often forced to comply with this state's criterion as opposed to boycotting it. This forces producers to raise their standard of production to meet the standard of the state that controls

\footnotetext{
${ }^{51}$ Tom Valtin, California Emissions Bill Paves Way for Cleaner Cars, supra note 4.

${ }_{52}$ E-mail from Tom Moye, Manager of Mobile Source Section, Vermont's Air Pollution Control Division, to Matthew Weinbaum, University of Michigan (Feb 18, 2003).

${ }^{53}$ Mark Martin, supra note 3, at A1.
} 
the significant portion of the market.54 Then, in order to keep production costs down, producers use the highest standard, the wealthy state's standard, as the model for all states in order to develop a uniform measure of production. As a result, the higher standard of a wealthy state is likely to develop into the corresponding standard for others.

A hypothetical scenario of what could happen if California enacts further-reaching automotive emission controls better explains the notion of Trading Up in relation to the thesis. From this, environmental interest groups can understand why it is crucial to first attack California automotive emissions policy if they wish to affect national and perhaps international climate change regulations.

California's State government decides that due to the negative effects increasing levels of air pollution have for its citizenry something must be done. Recognizing that automobiles are a prime source of greenhouse gas emissions within the state, California enacts a law with tougher automotive emission standards than any current national law. As a result, car manufacturers have three choices. They can make two separate lines of cars, boycott California's market or produce one line of cars at the higher California standard for the entire US. The decision made will be based on a cost-benefit analysis completed by the automotive companies. If the state enacting this law had a small automotive market, this decision would be easy. The automotive producers could simply boycott the state and refuse to sell cars there. The manufacturers would take a loss, but the cost of doing this would be less than if they had to make two lines of cars or if they produced one line of cars at the higher regulatory standard. However, California and all those states that accepted California's car emission standard capture a significant portion of the national car market. This makes the cost associated with boycotting the market for California's standard or producing two lines of cars likely to be higher than if only one national standard based on California regulations was enacted. As a result, it is likely that there is a smaller cost in developing the higher California standard. Thus, California's standard supplants the national standard as the one used by automotive manufacturers.

In addition to improving the domestic benchmark, there is evidence that points toward how an increase in California's automotive regulations can improve international automotive standards as well. Germany, one of Europe's principle automotive manufacturers, is pressing the European Union (EU) to adopt standards for European cars that are comparable to that of California's. This is because half of all German auto sales in the United States are from within California. Therefore it makes sense for Germany to push the EU to adopt standards according to California regulations. By doing this, German producers

\footnotetext{
${ }^{54}$ See Trading Up, supra note 11, at 260.
}

can manufacture automobiles for both markets using one standard at a lower cost.55

Understanding California's potential influence in car markets outside its jurisdiction, environmentalists should value the state's ability to force car manufacturers to Trade Up. Every car manufacturer wants to make sure that their production costs are the lowest that they can possibly be. As a result, it is important to be aware that the lowest costs for producers often occur when all standards of automotive production are uniform. Thus, if California raises its standards, it is likely that the manufacturers' standards will be forced to improve as well.

\section{CA-Environmental Severity, Affluence and Legislative Professionalism}

Although California can accept more stringent automotive emission restrictions such as $\mathrm{AB} 1493$ and as a result force car manufacturers to adopt a new standard, this does not explain why this type of legislation is passed. Some state politicians purport that $\mathrm{AB} 1493$ was passed because Californians actually have a greater desire than other Americans to maintain and improve upon the natural environment. As California Governor Gray Davis states:

\begin{abstract}
Acting decisively and showing leadership is what California has always done. That is what we are doing today with a law [AB 1493] that will benefit all of us here today as well as our children and their children who may be born decades from now. We don't often have a chance to vote for or sign a bill we are positive will be remembered long after we are gone. We can be sure we will have earned the gratitude of Californians and other Americans who will follow us.56
\end{abstract}

The notion of Californians as chief preservationists is also purported by CalEPA secretary Winston Hix:

\begin{abstract}
It is 'us', as a society that express ourselves and draw lines in terms of our preferences. Our area is so beautiful and so deserving of preservation that it leads us to protect the coast in a variety of ways: water quality, waste disposal, trash and air pollution as well. There were trends driving us into a damaged environment, but I think the people of California never would let that happen.57
\end{abstract}

While protecting the state's natural environment may have been one of the reasons why the majority of Californians supported AB 1493, they would not have been in favour of this bill, or any previous environmental legislation, regardless of its associated costs. Rather, in Norman Vig and Michael Kraft's report, Environmental Policy, it is alleged that; "we [governments/citizens] should undertake

\footnotetext{
${ }^{55} I d$. at 261.

${ }^{56}$ See Press Release, Gray Davis, Governor Davis Signs Historic Global

Warming Bill (July 22, 2002) (on file with

$<\mathrm{http}: / /$ www.arb.ca.gov/gcc/pressrel.htm>).

${ }^{57}$ See History of California Environmental Protection Agency, CalEPA.
} 
more pollution control activities only if the results are worth more to us than the value we forgo by diverting resources from other uses such as producing food, shelter and comfort".58 Therefore, the implementation of pollution control laws at any level of governance is a delicate balancing act between economic costs and environmental protection. If there is a pressing need or desire among citizens of a jurisdiction to improve their air quality, they are more likely to accept economic costs in order to achieve their desired level of environmental protection. In other words, two primary factors can influence a state to adopt stronger air pollution measures: 1) a high level of economic affluence, and 2) noticeable environmental problems. These are two characteristics of California that, along with a state legislature that is responsive to the needs and wants of its constituency, helps to explain why the state is consistently a supporter of progressive environmental legislation.

A high level of wealth is important for any state to enact progressive air quality measures as wealthier states can both demand and afford pollution control programs.59 When states are comprised of a relatively affluent tax base, the cost of compliance with more stringent regulations and laws is not necessarily sufficient to force citizens to choose between competitiveness and higher regulatory standards. 60

Table 3-1: Median Household Income

\begin{tabular}{l|ll}
\hline Year & United States & California \\
\hline 1980 & $\$ 16,481$ & $\$ 18,243$ \\
1990 & $\$ 30,056$ & $\$ 35,798$ \\
2000 & $\$ 41,994$ & $\$ 47,493$ \\
\hline
\end{tabular}

Table 3-2: GDP/Capita

\begin{tabular}{l|ll}
\hline & United States & California \\
\hline 1980 & $\$ 6,695$ & $\$ 8,295$ \\
1990 & $\$ 14,420$ & $\$ 16,409$ \\
2000 & $\$ 21,587$ & $\$ 22,711$ \\
\hline
\end{tabular}

In comparison with other US states, California has had higher levels of both GDP/Capita and median household income for over twenty years as described in tables 3-1 and 3-2.61 Therefore it is possible that more stringent environmental legislation would not significantly decrease the Golden State's competitiveness with other US states. Consequently, the overall affluence within California is one explanation for why Californians are more willing to accept stronger environmental standards than people in other regions of the US.

\footnotetext{
${ }^{58}$ See Environmental Policy, supra note 41 at 191.

${ }^{59}$ See Environmental Protection at the State Level, supra note 25 at 107.

${ }^{60}$ See Trading Up, supra note 11 , at 257.

${ }^{61}$ 1-49, 1-344 US BUREAU OF THE CENSUS, CENSUS OF THE POPULATION: CharaCteristics OF THE POPULATION 153 (1980); See also State and County Quick Facts: California, US Census Bureau, at

$<$ http://quickfacts.census.gov/qfd/States/06000.html> (visited Dec 11, 2002).
}

Another factor that explains why innovative automotive emission control legislation is supported by California's citizenry is the level of environmental threat that air pollution has for the state. Although some scientists and economists point out that the danger of greenhouse gases for the planet as a whole is not truly known, the emission of these gases is seen by Californians as a nagging public evil.62 This is because emissions of greenhouse gases in California are linked to higher temperatures within the state. This is evidenced by ten of the warmest years of the last century occurring within the last fifteen years. 63

Warmer temperatures are a problem for California because they are linked to an increase in smog in the Los Angeles Basin.64 In addition, warmer temperatures are ultimately creating warmer winters for the state as a whole. Due to these warmer winters, there is an earlier snowmelt and a reduced snow pack for California's principal reservoir, the Sierra Snow Pack. Over the past 90 years there has been a $10 \%$ decrease in spring runoff from this reservoir that has negatively affected the state's water supply. Additionally, increased greenhouse gas emissions are also linked within California to a rise in sea level along the valuable California coastline. Over the past 150 years there has been a seven-inch rise in sea level along the San Francisco coast.65

Regardless of whether greenhouse gas emissions negatively affect the health of Los Angeles residents or pose a threat to California's water supply, the severity of California's air pollution raise the citizenry's willingness to address the problem. This is seen as more than half of California's residents acknowledge that they will have to make lifestyle changes in order to address present environmental troubles.66 As a result, a decrease in the state's air quality is another reason why Californians may be more willing to enact stricter automotive regulations than the rest of the United States. However, Californian outcry and willingness to improve air pollution only matters if the state legislature is responsive to the needs of its constituents. As Evan Rinquist explains, legislative professionalism and inter-party competition within a state are essential components for ensuring the passage of state laws in concordance with the public's desire for more stringent environmental standards;

With better-educated members, more resources, and more staff support, professional legislatures have the time and the capacity to examine issues in depth and thus

\footnotetext{
${ }^{62}$ This is seen in a Public Policy Institute of California study. In this study, $72 \%$ of Californians identified air pollution within their region as being at least 'somewhat of a problem.' Additionally, the number of people who see air pollution as being a 'big problem' within their region of California has risen steadily from $28 \%$ to $34 \%$. See Special Survey, supra note 44 , at 6.

${ }^{63}$ See California Air Resource Board, Global Warming and the Greenhouse Gas Emissions from Automobiles, supra note 37.

${ }^{64} \mathrm{Id}$.

${ }^{65} I d$.

${ }^{66}$ See Special Survey, supra note 44, at VI.
} 
develop more innovative and comprehensive policy solutions. The assumption is that [inter-party] competition forces political parties to try and obtain the support of a large group of 'have-nots' within the population and social programs are the incentive offered to gather that support. While environmental groups can not be considered 'havenots' in the economic sense, environmental concerns have traditionally received less attention in state policy activities. 67

When viewing the California Legislature's website, it is evident that the state has a professional legislature that is responsive to the needs of its citizenry. On this website, there is a page dedicated to constituent input on particular assembly bills currently debated in the House and Senate. Californians can provide feedback regarding particular legislation directly on this webpage. These comments are then forwarded to the author of the bill in question.68 Additionally, every Assembly member and State Senator has their own personal websites and e-mail addresses through which questions or comments can be directed at them from citizens within their jurisdiction.69 Furthermore the State of California has over thirty standing committees, sixty select committees, nine joint committees, two special committees and six different caucuses to represent Californian concerns and distinct California interest groups.

It is evident that a number of factors influence the state's decisions to implement progressive environmental policy. Among the state's citizens, there is a desire to improve the air quality problems within California and a willingness to accept economic costs in doing so. Additionally, the state has a professional legislature in which California assembly members are willing and able to address the concerns of the citizenry. As a result, the passage of $\mathrm{AB} 1493$ is not an anomaly. Environmental interest groups should aim at California to improve climate change regulation because California citizens want to improve their air pollution problems and the state legislature is responsive to its constituents needs.

\section{Conclusion}

During the past three years of the George W. Bush administration, the United States has rejected the Kyoto Protocol and instead promoted The Clear Skies Initiative. As previously mentioned, this new legislation does little, if anything, to alleviate carbon dioxide, potentially the greenhouse gas most responsible for atmospheric pollution. 70 As a result, it is only logical for those wishing

\footnotetext{
${ }^{67}$ See Environmental Protection at the State Level, supra note 25, at 108.

68 See Comment on an Assembly Bill, California State Assembly, at $<$ http://www.assembly.ca.gov/acs/acsframeset2text.htm $>$ (visited April 23, 2003).

${ }^{69}$ See Assembly member one-line listing of all members sorted by Assembly Member last name, California State Assembly, at $<$ http://www.assembly.ca.gov/acs/acsframeset7text.htm $>$ (visited April 23, 2003)

${ }^{70}$ James O. Goldsborough, The Illusion of US Energy Independence, SAN DiEgo Union-Tribune, May 2, 2002, at B13.
}

to counter global warming to aim at other levels of government in the United States to help address the problem.

The State of California is an arena in which the long term, uncertain effects of global warming are transformed into a nagging public goods problem in the present. The historical air pollution problems in the state; increased smog in the Los Angeles Basin, shrinking snow melts and rising oceans along the shoreline have influenced the state's legislature to take the initiative to remediate these problems. Over the past fifty years, the state has displayed a willingness to enact legislation countering air pollution ahead of the rest of the nation.

As a result, environmental interest groups should focus on California if they wish to enact an effective global warming policy with worldwide effects. The passage of $A B$ 1493 exemplifies this notion. Where the federal government has failed to curb this potentially dangerous problem, the State of California has taken the initiative to do so. As a powerful and wealthy state, in and of itself, California has the influence, capacity and desire to affect future automotive emission regulations. It is now up to those who wish to enact more stringent policies in the future to recognize when the time is right to improve upon $\mathrm{AB}$ 1493.0

\section{Works Cited \\ Books}

1-49, 1-344 US Bureau of the Census. Census of the Population: Characteristics of the Population, 153 (1980)

Kraft, Michael E. and Norman J. Vig. Environmental Policy 196, 191- 96 (2000)

Lowry, Will. The Dimensions of federalism: State governments and pollution control policies, 92 (1992)

Moore, Thomas Gale. Climate of Fear, 3 (Cato Institute 1998)

Parsons, Michael. Global Warming: The Truth Behind the Myth, 241 (Insight Books 1995)

Rinquist, Evan J. environmental protection at the State level: politics and progress in controlling pollution, 105-108 (1993)

Vogel, David. Trading Up: Consumer and Environmental Regulation in a Global Economy, 259 (2nd Ed 1995)

\section{Internet \& Electronic Media}

About: Cal/EPA Office of the Secretary, California Environmental Protection Agency, at http://www.calepa.ca.gov/About/OfficeSec.htm (visited Feb 6, 2003). 
Air Resource Board, CalEPA, at http://www.calepa.ca.gov/about/History01/arb.htm (visited Sept 27 ,

2002).

Alliance of Automotive Manufacturers, About the Alliance, at http://www.autoalliance.org/about.htm (visited April 3, 2003).

Appendix B: Description of Litigation Involving the Zero Emission Vehicle Regulation, California Environmental Protection Agency, at http://www.arb.ca.gov/regact/zev2003/appb.pdf (visited April 4, 2003).

Assembly Bill 1493: Legislation to Reduce Global Warming Pollution From New Passenger Vehicles, Bluewater Network, at http://www.bluewaternetwork.org/reports/rep_ca_global_ab1493f $\begin{array}{llll}\text { acts.pdf } & \text { (visited } & \text { Sept } & \text { 2002) }\end{array}$

Assembly member one-line listing of all members sorted by Assembly Member last name, California State Assembly, at http://www.assembly.ca.gov/acs/acsframeset7text.htm (visited

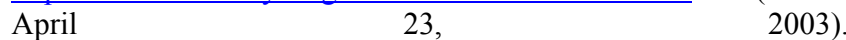

California Air Quality History - Key Events, California Air Resource Board, at $\underline{\text { http://www.arb.ca.gov/html/brochure/history.htm (visited April }}$ 10 ,

2003).

California Air Resource Board, Global Warming and the Greenhouse Gas Emissions from Automobiles, at www.arb.ca.gov/gcc/092602board/092602bdpres.pdf (visited Dec 11

2002).

California Department of Finance, Environmental Protection, 2003 - 04 Governor's Budget, at http://www.osp.dgs.ca.gov/OnLine+Publications/Governor's+Budget+2003-2004.htm (visited April 3, 2003).

California Taxpayers Association 2002 Legislative Voting Record, Assembly Members, at http://www.caltax.org/VoteScorecardAssembly.pdf (visited April 10 ,

Comment on an Assembly Bill, California State Assembly, at http://www.assembly.ca.gov/acs/acsframeset2text.htm (visited April 23, 2003).

E-mail from Tom Moye, Manager of Mobile Source Section, Vermont's Air Pollution Control Division, to Matthew Weinbaum, University of Michigan (visited Feb 18, 2003).

Fran Pavley, Biography, Assembly Member 41st District, at http://democrats.assembly.ca.gov/members/a41/default2.htm?biog raphy (visited $\quad$ April

History of California Environmental Protection Agency, CalEPA, at http://www.calepa.ca.gov/about/History01/calepa.htm (visited

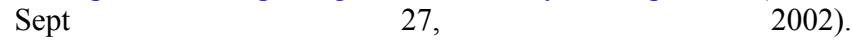

Howard Posner, Bill Analysis: AB 1493, California Legislative Information, at

http://www.leginfo.ca.gov/pub/0102/bill/asm/ab_14511500/ab_14
93 cfa 20020701191016 asm floor.html (visited April 10, 2003).

Natural Resources Defense Council, Automakers' Campaign of Lies and Distortion Against California's Clean Car Legislation, Clean Cars Now, at www.cleancarsnow.org/presskit/carmakerdistortions.pdf (visited May 6, 2003).

State and County Quick Facts: California, US Census Bureau, at http://quickfacts.census.gov/qfd/States/06000.html (visited Dec 11 ,

2002).

The Southland's War on Smog: Fifty Years of Progress Towards Clean Air, Southern Coast Air Quality Management District, at http://www.aqmd.gov/monthly/marchcov.html (visited April 3, 2003).

Tom Valtin, California Emissions Bill Paves Way for Cleaner Cars, Sierra Club, at http://www.sierraclub.org/planet/200209/cleaner cars.asp $\quad$ (last modified Sept/Oct, 2002).

\section{Law Reviews, Journals \& Magazines}

Baldassare, Mark, "PPIC Statewide Survey: Californians and Their Government”, Pub. Pol'y Inst. of Cal., Feb 2002, at VI.

-----, "Special Survey on Californians and the Environment", Pub. Pol'y Inst. of Cal., June 2002, at 6.

Rabe, Barry, "Greenhouse and Statehouse: The Evolving State Government Role in Climate Change", Pew Center on Global Climate Change, November 2002, at 9.

Letters, Press Release, Interviews, Speeches

Press Release, Gray Davis, Governor Davis Signs Historic Global Warming Bill (July 22, 2002) (on file with $<$ http://www.arb.ca.gov/gcc/pressrel.htm>).

Press Release, Josephine Cooper, Automakers Will Pursue Litigation to Protect California Consumers (July 22, 2002) (on file with Alliance of Automotive Manufacturers at www.autoalliance.org/pressreleases/pr072202.htm.

Press Release, The Natural Resources Defense Council, California's Clean Car Legislation (July 22, 2002) (on file with http://www.nrdc.org/media/pressreleases/020722.asp.

Telephone Interview with Chris Corwin, Bluewater Network (Oct 30 ,

2002).

Telephone Interview with Public Information Office, California Air Resource Board (February 17, 2003).

Telephone Interview with Sean Peterson, Staff Member for California Assemblywoman Fran Pavley (Oct 30, 2002) 


\section{Newspapers}

Booth, William, "California Takes Lead on Auto Emissions: Gov Davis to sign law on pollution that may affect all US drivers", Washington Post, July 22, 2001, at A1.

Chance, Amy, "Davis Keeps Lead on Simon: Despite Unfavorable Ratings, the Governor Edges His GOP Rival", Sacramento Bee, July 11 , 2002,

www.sacbee.com/content/politics/ca/election/polls/story/3528415 $\mathrm{p} \quad$ 4554552c.html.

Egan, Timothy, "Alaska, No Longer So Frigid, Starts to Crack, Burn and Sag", New York Times - Late edition, June 16, 2002, at Section 1, Page 1, Column 3

Garrett, Robert T., "Green Car Bill Stalls Again", The PressEnterprise, May 17, 2002, at A01.

Goldsborough, James O., "The Illusion of US Energy Independence", San Diego Union Tribune, May 2, 2002, at B13.

Hakim, Danny, "California is Moving to Guide US Policy on Pollution", The New York Times, July 3, 2003, at Section A, Page
1,

Column

5.

Haynes, Raymond, "Criminalizing Carbon Dioxide", Metropolitan News Enterprise, July 19, 2002, at 7.

“In Denial on Warming", Boston Globe, Dec 9, 2002, at A9.

Kurtzman, Laura, "Poll: Davis and Simon Both Losing Support Among Voters", Mercury News, Sept 4, 2002, at http://www.bayarea.com/mld/mercurynews/4004426.htm.

Martin, Mark, "Bill to Cut Greenhouse Gases Idles in Assembly", San Francisco Chronicle, May 22, 2002, at A21

-----, "State's air law to steer nation; Automakers fear spread of car emission policy", San Francisco Chronicle, July 21, 2002, at A1

"Mr. Bush Dissembles", The St. Louis Post - Dispatch, June 11, 2002, at B6.

Pianin, Eric, "On Global Warming, State Acts Locally at Odds With Bush's Rejection of Mandatory Cuts. Governors and Legislatures Enact Curbs on Greenhouse Gases", Washington Post, Nov 11, 2003, at A03. 